\title{
KEBIJAKAN STRATEGIS PT. ANEKA TAMBANG TBK
}

\author{
STRATEGIC POLICY OF PT. ANEKA TAMBANG TBK
}

\author{
Ruswana $^{* 11}$, M. Syamsul Ma'arif *), dan Kirbrandoko ${ }^{* *}$ \\ ${ }^{*}$ Sekolah Bisnis, IPB University \\ Jl. Raya Pajajaran, Bogor 16151, Indonesia \\ ${ }^{* *}$ Universitas Ibn Khaldun Bogor \\ Jl. Sholeh Iskandar, Bogor 16162, Indonesia
}

\begin{abstract}
Ferronickel Production from 2014 to 2018 the highest record was 24,868 Tni or grew 47.5\% over the past five years. Alumina Production from 2016 to 2018 has continued to decline. Gold production in the last five years has continued to decline too, While ANTAM's competitors, such as Tsingshan Group for Nickel, Harita Group for Bauxite and Agincort for Gold, showed a performance that exceeded ANTAM. This research was conducted to analyze the strategic policies taken by ANTAM whether they are in accordance with the market situation and the competition map in the mining industry. The research data was obtained through ANTAM's Annual Report and the Annual Report of several other mining companies and other data through the internet media. Strategy Analysis uses 3 stages, stage one to input matrix of the Internal Factor Analysis and External Factor Analysis, stage two matching uses the SWOT Matrix, SPACE Matrix, BCG Matrix, IE Matrix, and GRAND STRATEGY Matrix, as well as stage three selection of strategy using the QSPM matrix. The results showed that the strategy chosen was in accordance with current strategy ANTAM, i.e aggressive, growing, building intensively and integratively through forward integration, backward integration, horizontal integration, product development, market penetration, market development, and related diversification, but in the implementation process it still needed corrections to make adjustments so that the strategy went well.
\end{abstract}

\section{Keywords: SWOT Matrix, SPACE Matrix, BCG Matrix, IE Matrix, QSPM Matrix}

\begin{abstract}
Abstrak: Produksi Feronikel dari 2014 hingga 2018, rekor tertinggi adalah 24.868 Tni atau tumbuh 47,5\% selama lima tahun terakhir. Produksi Alumina dari 2016 hingga 2018 terus menurun. Produksi emas dalam lima tahun terakhir juga terus menurun, sementara pesaing ANTAM, seperti Grup Tsingshan untuk Nikel, Grup Harita untuk Bauksit dan Agincort untuk Emas, menunjukkan kinerja yang melebihi ANTAM. Penelitian ini dilakukan untuk menganalisis kebijakan strategis yang diambil ANTAM apakah sesuai dengan situasi pasar dan peta persaingan di industri pertambangan. Data penelitian diperoleh melalui Laporan Tahunan ANTAM dan Laporan Tahunan beberapa perusahaan pertambangan lainnya serta memperoleh data lain melalui media internet. Analisis Strategi menggunakan 3 tahap, tahap satu input matriks Analisis Faktor Internal dan Analisis Faktor Eksternal, tahap kedua pencocokan menggunakan Matriks SWOT, Matriks SPACE, Matriks BCG, Matriks IE, berikutnya Matriks Strategi Besar, serta pemilihan strategi tahap tiga menggunakan matriks QSPM. Hasil penelitian menunjukkan bahwa strategi yang dipilih sesuai dengan strategi ANTAM saat ini yaitu agresif, tumbuh, membangun intensif dan integratif dengan melalui integrasi kedepan, integrasi kebelakang, integrasi horizontal, pengembangan produk, penetrasi pasar, pengembangan pasar, serta diversifikasi terkait, tetapi dalam proses implementasi masih perlu koreksi untuk melakukan penyesuaian agar strategi berjalan dengan baik.
\end{abstract}

Kata kunci: Matriks SWOT, Matiks SPACE, Matriks BCG, Matriks IE, Matriks QSPM

\footnotetext{
${ }^{1}$ Alamat Korespondensi:

Email: ruswana@gmail.com
} 


\section{PENDAHULUAN}

Indonesia merupakan salah satu negara kaya sumber daya mineral tambang seperti nikel, bauksit, timah, emas, perak, tembaga dan lainnya, tetapi mineral tersebut belum bisa memakmurkan bangsa dan negara sebagaimana diamanatkan dalam Pasal 33 UUD 1945, hal ini disebabkan karena bahan-bahan tambang tersebut lebih banyak dieksport dalam bentuk bijih (mentah) dengan nilai jual yang rendah. Untuk meningkatkan pendapatan negara maka perlu dilakukan proses hilirisasi yaitu merubah bahan mentah menjadi barang yang add value.

Menurut Ika (2017) ada 5 urgensi terkait dengan kebijakan hilirisasi yang diamanatkan oleh UU No.4 Tahun 2009, yaitu: mendorong pendirian smelter di dalam negeri, mengintegrasikan operasi huluhilir-industri, mendorong peningkatan nilai tambah, mendorong peningkatan penerimaan negara, dan menegakan kedaulatan mineral. Namun, sampai saat ini sektor pertambangan Indonesia belum memperlihatkan kemajuan ditandai lambatnya para pengusaha tambang Indonesia di sektor pertambangan mineral membangun pabrik pengolahan dan pemurnian sebagai amanat UU No.4 Tahun 2019 serta kinerja yang menurun ditandai dengan banyaknya perusahaan yang berhenti dari rencana kegiatannya. (Haryadi, 2017). Di Indonesia yang mempunyai sejarah sudah melakukan hilirisasi tambang adalah PT. Aneka Tambang Tbk (ANTAM), PT. Inco Tbk (sekarang Vale), dan PT. Smelting Gresik (PTSG), tetapi karena kapasitas smelternya kecil hanya mampu menyerap sumberdaya yang sedikit, sehingga sumberdaya yang berlebih dieksport dalam bentuk mentah.

Terdapat penurunan secara kuantitas ekspor, akibat adanya regulasi berupa Undang-Undang Minerba No.4 Tahun 2009 dan Permen ESDM No.7 Tahun 2012, disebutkan pemerintah mendorong adanya ekspor mineral yang mempunyai nilai tambah. Dengan menurunnya jumlah ekspor mineral jelas berpengaruh pada dunia bisnis sektor mineral.(Suprapto et al. 2017). Perubahan bisnis sektor mineral ini mempengaruhi ANTAM yang pada tahun 2014 dan 2015 mengalami kerugian yang signifikan (Annual Report Antam, 2014 dan 2015). Oleh karena itu perubahan terjadi di ANTAM, dengan dikeluarkannya keputusan Direksi ANTAM pada tahun 2014, yaitu ANTAM menetapkan Visi 2030 dengan statement "Menjadi korporasi global terkemuka melalui diversifikasi dan integrasi usaha berbasis sumber daya alam". Sesuai dengan visi tersebut terkandung bahwa ANTAM berkeinginan untuk berkembang sebagai perusahaan berbasis sumber daya mineral terdepan di Indonesia dan menetapkan perannya dalam industri hilir sebagai pemasok material antara untuk keperluan produksi industri-industri terkait. Proses hilirisasi yang dilakukan oleh ANTAM bernilai strategis karena untuk meningkatkan added value untuk raw material yang dihasilkan oleh ANTAM yaitu bahan mentah nikel, bauksit serta emas, sehingga akan meningkatkan profit ANTAM, yang selanjutnya dapat dinikmati oleh Rakyat Indonesia dalam bentuk deviden. Oleh karena itu, kegiatan hilirisasi di ANTAM perlu diketahui sampai sejauh mana prosesnya dan kendala yang dihadapi, kemudian apakah kemajuannya sudah maksimal dibandingkan dengan hilirisasi yang dilakukan oleh perusahaan sejenis yang ada di Indonesia. Berikut data-data terkait hilirisasi yang telah dilaksanakan di ANTAM berserta dengan pesaingnya:

\section{Produksi Ferronickel ANTAM}

ANTAM mempunyai Smelter Ferronickel yang ada di Pomalaa Sulawesi Tenggara dengan kapasitas 25.000 TNi per tahun. Saat ini sedang menyelesaikan Smelter Haltim di Maluku Utara dengan kapasitas 13.000 TNi per tahun, tahun 2019 diharapkan terlah berjalan. Untuk smelter lainnya menunggu kerjasama dengan mitra baik itu dalam negeri maupun luar negeri. Berdasarkan Gambar 1 Produksi Ferronickel ANTAM selama lima tahun terakhir dari tahun 2014 sampai dengan 2018 rekor tertinggi adalah $24.868 \mathrm{TNi}$, atau dengan perkataan lain Produksi Ferronickel ANTAM tumbuh 47.5\% selama lima tahun, sedangkan PT. Tsingshan Morowali dalam dua tahun, terjadi pertumbuhan untuk Ferronickel sebesar $116 \%$. Peningkatan yang signifikan tersebut kemungkinan disebabkan inovasi pengolahan bijih yang lebih sederhana dan produksi yang tinggi.

\section{Produksi Alumina}

ANTAM mempunyai Chemical Grade Alumina (CGA) di Tayan Kalimantan Barat yang sudah produks. Saat ini juga ANTAM sedang melakukan kontruksi Smelter Grade Alumina (SGA) di Mempawah Kalimantan Barat. Peta persaingan produksi Alumina di Indonesia seperti terlihat pada Gambar 2, hilirisasi di Bauksit, produksi Alumina ANTAM dari tahun 2016 sampai dengan 2018, terlihat bahwa produksi Alumina turun dalam tiga tahun terakhir, sedangkan dapat dilihat juga produksi alumina pesaing ANTAM seperti terlihat pada 
Gambar 2 bahwa Produksi Alumina ANTAM tertinggal oleh PT. Harita Prima Abadi Mineral (Harita Group).

Produksi Emas

ANTAM berkonsentrasi di proses pengolahan dan pemurnian emas dan perak yang terletak di Jakarta sebagai Unit Logam Mulia, yang sudah mempunyai akreditasi LBMA (London Bullion Market
Assosiation). Produksi Emas ANTAM serta pesaingnya dapat dilihat pada Gambar 3, terlihat dalam lima tahun terakhir ANTAM mengalami penurunan terus, hal ini mengakibatkan pasokan untuk Pabrik Pengolahan dan Pemurnian Emas tidak dapat mengandalkan dari Tambang Emas ANTAM sendiri. Peta persaingan produksi emas di Indonesia dapat dilihat juga pada Gambar 3, pesaing ANTAM terus mengalami peningkatan, melebihi produksi ANTAM.
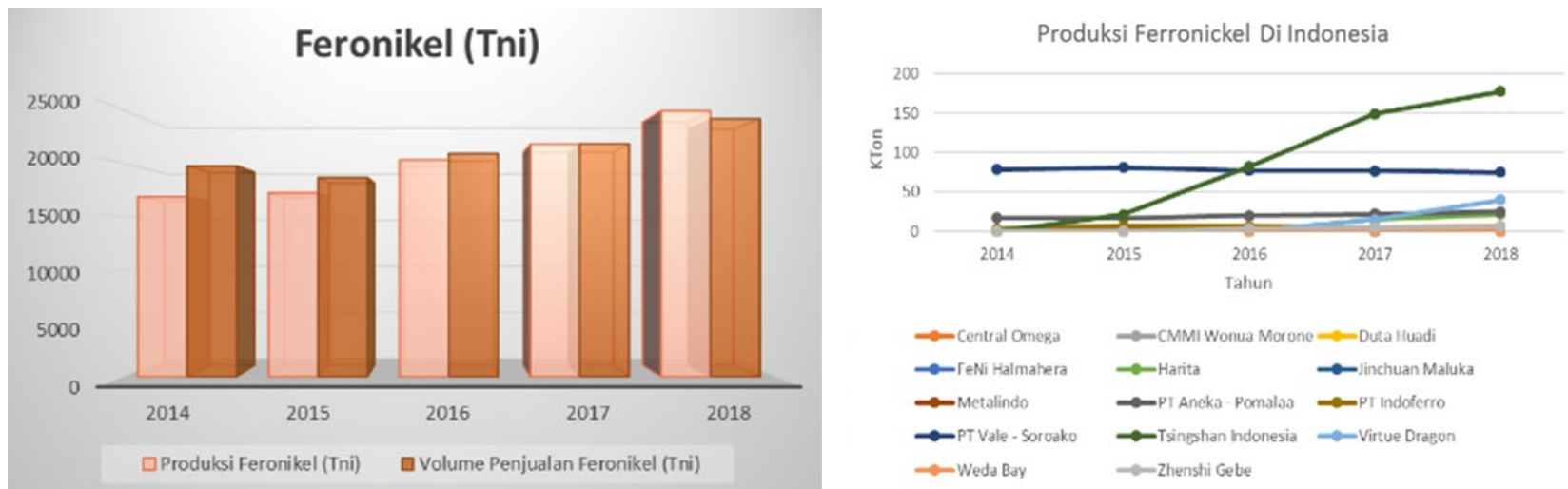

Gambar 1. Produksi dan Volume Penjualan Ferronickel (Annual Report ANTAM 2014-2018 dan Wood Mackenzie 2018).

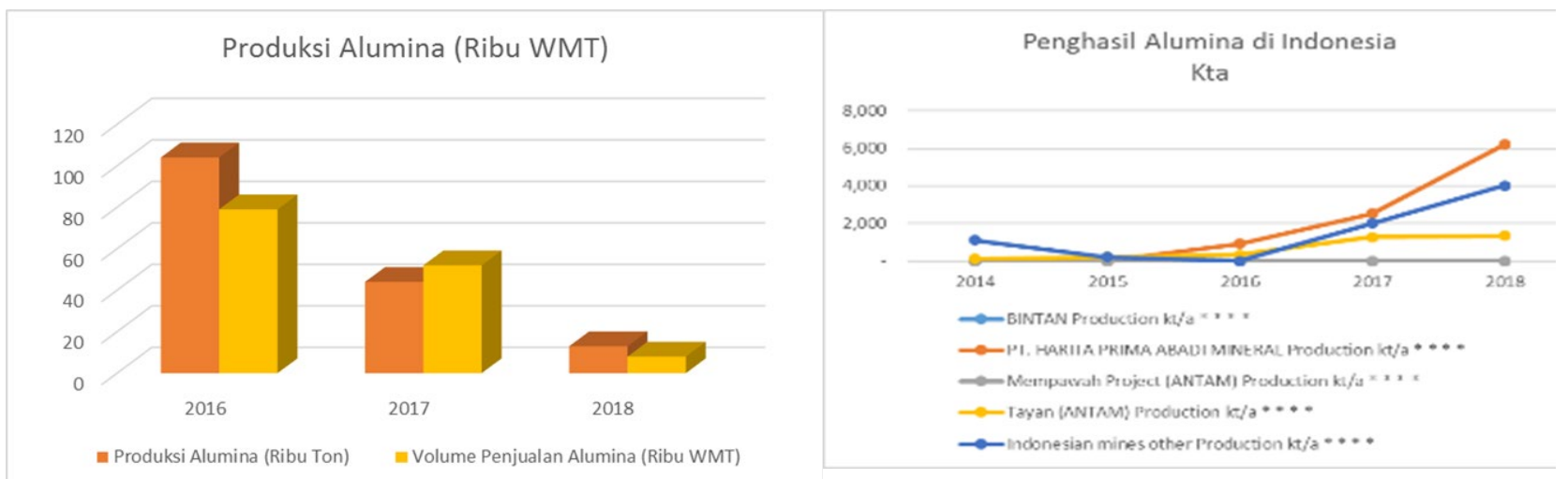

Gambar 2. Produksi dan Volume Penjualan Alumina (Annual Report ANTAM 2014-2018 dan Wood Mackenzie 2018).
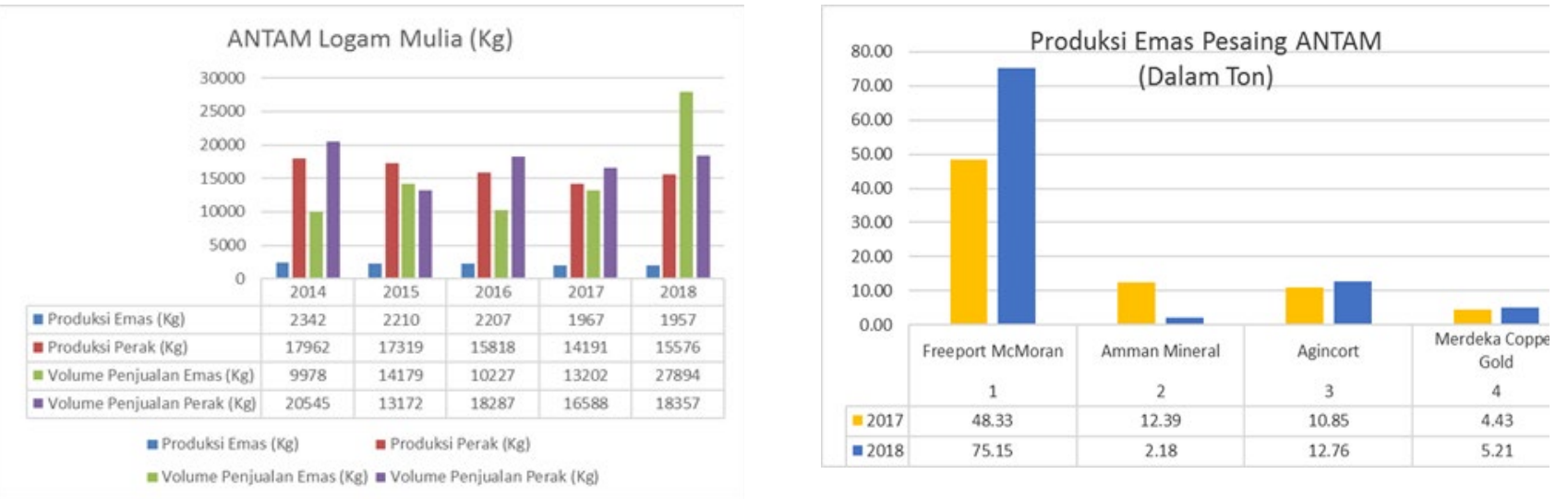

Gambar 3. Produksi dan Volume Penjualan Emas (Annual Report ANTAM, Freeport, Agincort, Medco dan Merdeka CG 2014-2018) 
Berdasarkan Gambar 1, Gambar 2, dan Gambar 3 terlihat bahwa proses hilirisasi di ANTAM lebih lambat dibandingkan dengan perusahaan lainnya yang ada di Indonesia, terutama untuk komoditas nikel dan bauksit, permasalahan yang muncul adalah kenapa hilirisasi di ANTAM lebih lambat dengan perusahaan lain?. Kondisi tersebut perlu dianalisis apakah terjadi kesalahan strategi dalam membangun proses hilirisasi ANTAM? ataukah kebijakan strategi yang dipilih tidak berjalan dengan baik?. Maka dalam penelitian ini akan dibahas terkait lambatnya proses hilirisasi di ANTAM dikaitkan dengan Strategi yang diterapkan oleh ANTAM selama kurun waktu 5 tahun terakhir. Adapun tujuan dari penelitian Analisis Kebijakan Strategis Pada ANTAM adalah mengevaluasi kondisi ANTAM 5 tahun terakhir dari tahun 2014 s.d. 2018 terkait dengan strategi yang dijalankan terkait dengan perubahan situasi pasar, perkembangan ekonomi, adanya pendatang baru dan perkembangan teknologi. Selanjutnya, membuat formulasi kebijakan strategis yang sesuai dengan perubahan eksternal dan internal.

\section{METODE PENELITIAN}

Tempat penelitian yang digunakan yaitu ANTAM yang terletak di Jalan TB Simatupang Jakarta Selatan. Data yang digunakan adalah Annual Report ANTAM yang diunduh dari Website resmi ANTAM yaitu www. antam.com. Seri data yang digunakan untuk penelitian ini, dalam kurun waktu 5 tahun yaitu dari 2014 s.d. 2018.

Penelitian ini menggunakan metode deskriptif kuantitatif untuk menganalisis strategi ANTAM. Penggunaan metode deskriptif untuk memberikan gambaran mendalam terhadap permasalahan penelitian dengan data yang dinyatakan dalam bentuk angka. Melakukan observasi dan deep interview pakar diantaranya VP Business Development, VP Corporate Strategic dan VP Exploration Planning and Mining Development.

Jenis dan sumber data yang dibutuhkan pada penelitian ini adalah data primer dan sekunder. Data primer diperoleh melalui wawancara dengan pakar. Data sekunder dalam penelitian ini meliputi annual report ANTAM 2014-2018, annual report pesaing ANTAM, Konsultan Research Woodmac 2014-2018, jurnal, tesis, disertasi serta buku teks yang relevan dengan tema penelitian. Data sekunder yang diperoleh akan dijadikan landasan dan rujukan dalam menginterpretasikan hasil penelitian.

Prosedur analisis data untuk penelitian ini dapat dilihat secara diagram pada Gambar 4. Prosedur analisis data dimulai dari evaluasi strategik dengan memperoleh data internal dari pelaksanaan strategik yang berupa annual report ANTAM dari tahun 2014-2018, kemudian masukan untuk faktor eksternal diperoleh dari annual report pesaing ANTAM dan Laporan Lembaga Research Mineral, yaitu WoodMac, kemudian masuk ke Tahap Input dengan membuat matriks IFAS dan EFAS, dilanjutkan dengan membuat Competitive Profile Matriks (CPM), lanjut ke Tahap 2 pencocokan dengan membuat matriks berikut SWOT, SPACE, BCG, IE dan Grand Strategy. Kemudian dilanjutkan dengan pemilihan strategi dengan menggunakan Matriks QSPM, hasil dari strategi yang diperoleh dari evaluasi dibandingkan dengan strategi yang sudah berjalan, kemudian dianalisis yang menghasilkan implikasi manajerian, kesimpulan dan saran.

Teknik perumusan strategi dapat diintegrasikan dalam kerangka pengambilan keputusan tiga tahap (David, 2011) yaitu meliputi:

\section{Tahap 1}

Tahap 1 adalah tahap memasukan data-data yang diperlukan untuk mengukur subyektivitas selama tahap awal perumusan strategi. Tahap ini menurut (Sukanta, Sari, A Dessy, Darajat, Andhika, 2018) merupakan peringkas informasi dasar keadaan perusahaan secara internal dan eksternal. Proses tahap 1 input ini terdiri dari:

\section{Matriks External Factors Analysis Summary (EFAS)}

Memungkin para penyusun strategi untuk meringkas dan mengevaluasi informasi ekonomi, sosial, budaya, demografis, lingkungan, politik, pemerintah, hukum, teknologi dan kompetitif dalam bentuk matriks. Menurut Suciyanti et al. (2018), Apabila total nilai untuk faktor eksternal/EFAS semakin mendekati 1, berarti semakin banyak ancaman dibandingkan peluangnya. Apabila nilainya mendekati 4 , berarti semakin banyak peluang dibandingkan ancamannya 


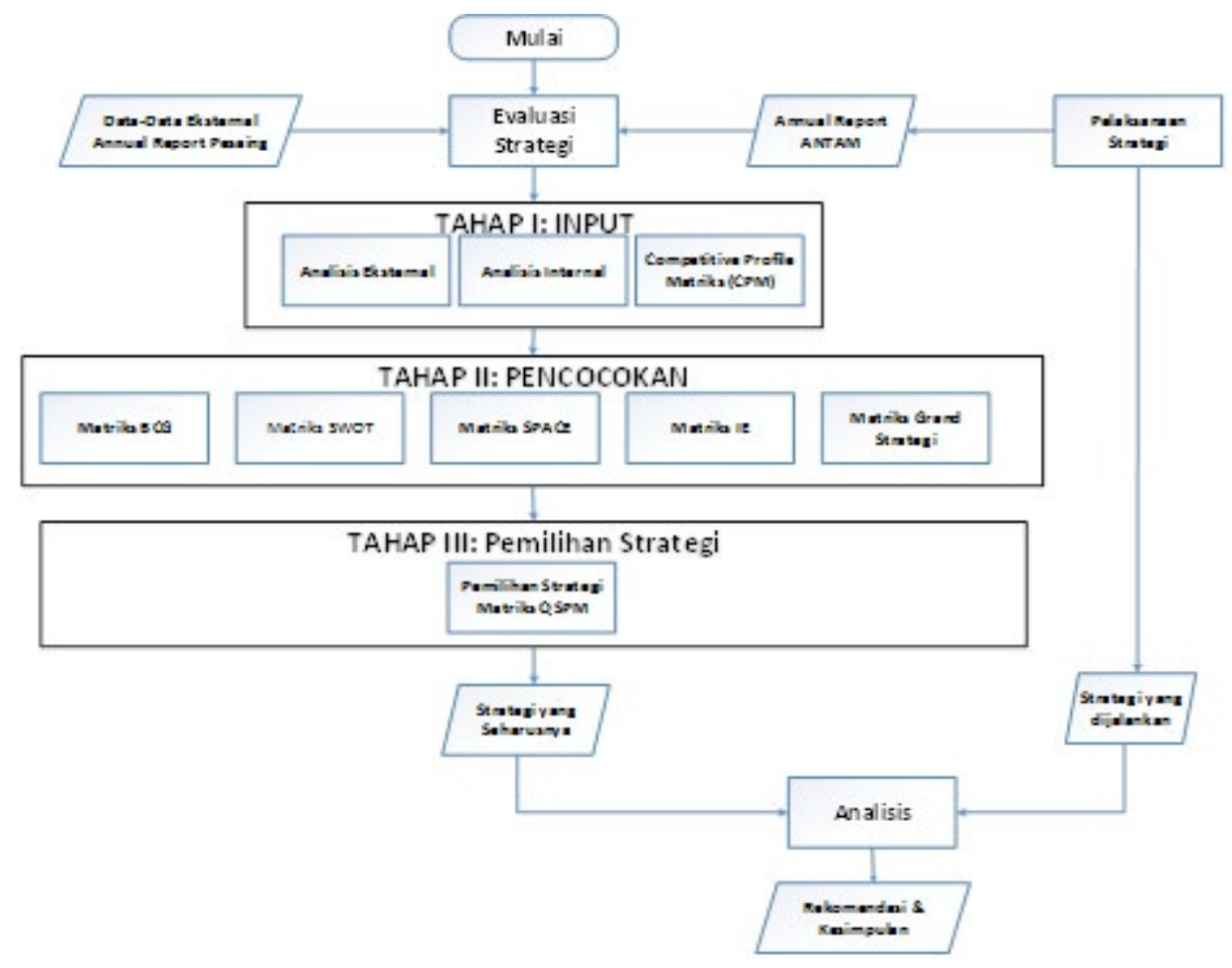

Gambar 4. Kerangka pemikiran penelitian

\section{Matriks Internal Factors Analysis Summary (IFAS)}

Alat perumusan strategi ini meringkas dan mengevaluasi kekuatan dan kelemahan utama dalam area-area fungsional bisnis, dan juga menjadi landasan mengindentifikasi dan mengevaluasi hubungan diantara area tersebut. Penilaian intuitif digunakan dalam pengembagan Matriks Evaluasi Faktor Internal, sehingga tampilan ilmiahnya tidak boleh ditafsirkan sebagai bukti bahwa teknik ini benar-benar tanpa celah. Menurut Suciyanti et al. (2018), apabila total nilai untuk faktor internal/IFAS semakin mendekati 1, berarti semakin banyak kelemahan dibandingkan kekuatannya. Apabila nilainya mendekati 4, berarti semakin banyak kekuatan dibandingkan kelemahannya.

\section{Matrik Profil Kompetitif (CPM).}

Mengenali kompetitor kita yang sudah ada atau yang baru muncul, menurut Kinasih et al (2015) CPM berguna untuk mengidentifikasi pesaing utama perusahaan serta kekuatan dan kelemahan mereka dalam hubungannya dengan posisi strategis dari perusahaan. Pengetahuan kelemahan dan kekurangan, dapat berupa informasi tentang apa yang dibutuhkan pelanggan, kapasitas mesin pabrik kita, keadaan jaringan pemasaran, komposisi sales representative kita, keadaan jaringan pemasok, hal-hal yang akan dilakukan oleh para pesaing, serta peluang-peluang yang mungkin ada. Apabila pengetahuan yang dimiliki dapat dikelola dengan baik dan efektif, maka keunggulan kompetitif perusahaan dapat dicapai dengan mudah.

\section{Tahap 2}

Tahap 2 adalah Tahap Pencocokan (Matching Stage), karena berfokus pada pembangkitan strategistrategi alternatif yang dapat dilaksanakan melalui penggabungan factor-faktor eksternal dan internal yang utama. Atau dengan kata lain pencocokan ini dibuat oleh suatu organisasi untuk mengetahui hubungan antara sumber daya dan keterampilan internal dengan peluang dan risiko yang diciptakan oleh faktor eksternal (Sutrisno, 2017), yang meliputi:

Matriks Strengths Weakness Opportunities Threats (SWOT)

Matriks SWOT dikembangkan oleh Wheelen dan Hunger. Kolom vertikal berisi External Factor Analysis Summary (EFAS), dan Baris horizontal berisi Internal Factor Analysis Summary (IFAS). Analisis ini berguna untuk mengetahui posisi perusahaan dalam pasar berdasarkan kekuatan, kelemahan, peluang dan ancaman yang dimiliki oleh perusahaan (Elyarni et al. 2016). 
Matriks Strategis Position and Action Evaluation (SPACE)

Matriks Strategic Positioning and Action Evaluation (SPACE) menunjukkan apakah strategi yang paling sesuai untuk organisasi adalah strategi agresif, konservatif, defensif, atau kompetitif (Hindarwati et al. 2016). Dalam matriks ini terdapat empat kerangka kuadran yang dapat menentukan apakah agresif, konservatif, defensif, atau kompetitif kah yang paling sesuai dengan organisasi tersebut.

\section{Matriks Boston Consulting Group (BCG)}

Matriks Boston Consulting Group (BCG) merupakan teknik portofolio analisis dengan memetakan kinerja unit bisnis perusahaan berdasarkan pangsa pasar relatif dan tingkat pertumbuhan industrinya (Guntara et al. 2017). Kegunaan dari matriks BCG pada manajemen perusahaan adalah sebagai acuan dalam mengalokasikan dana, memproduksi dan menjual produknya. Matriks BCG ini berkaitan erat dengan siklus hidup produk atau Products life cycle sehingga sering disebut juga dengan Product Portfolio Matrix atau Matriks Portofolio Produk.

\section{Matriks Internal-Eksternal (IE)}

Matriks yang menggunakan parameter Kekuatan Internal perusahaan dan Pengaruh Eksternal yang dihadapi. Tujuan penggunaan model ini adalah untuk memperoleh strategi bisnis ditingkat korporat yang lebih detail (Winardi, 2014). Matriks internal eksternal membantu mengetahui posisi perusahaan ke dalam 9 sel. Matriks ini terdiri dari 2 dimensi, yaitu total skor matrik IFE pada sumbu X dan matriks EFE pada sumbu Y.

\section{Matriks Grand Strategy}

Matriks Grand Strategy telah menjadi salah satu alat analisis yang populer untuk merumuskan strategi alternatif. Analisis ini diaplikasikan dalam sebuah diagram yang terbagi dalam empat kuadran. Bertujuan untuk mengetahui posisi perusahaan dan perkembangannya, yang digambarkan dalam 4 kondisi yang berbeda (Maulana et al. 2019). Untuk unit-unit bisnis dapat dilakukan hal yang serupa.
Tahap 3

Tahap 3 adalah Keputusan, melibatkan satu teknik saja, yaitu Matriks Perencanaan Strategis Kuantitatif (Quantitative Strategic Palnning Matrix - QSPM). QSPM menggunakan informasi input Tahap 1 untuk mengevaluasi strategi-strategi alternatif yang diindentifikasi dalam Tahap 2.

\section{HASIL}

\section{Tahap Input}

Sebagai tahap input berikut adalah formulasi strategi dengan membuat matriks IFE dan EFE berdasarkan observasi dan interview. Observasi dilakukan dengan melihat secara langsung kegiatan-kegiatan yang dilakukan oleh ANTAM yang terlihat dari laporan-laporan secara internal maupun untuk kebutuhan publik. Interview terhadap personil yang strategis seperti VP Corporate Strategic, VP Business Development dan VP Exploration Planning Mining Development.

\section{Membuat EFAS dan IFAS}

Tabel 1, peluang dengan bobot yang paling tinggi adalah kepercayaan investor ke brand ANTAM dan dukungan pemerintah untuk hilirisasi industri pertambangan, hal ini disebabkan karena kepercayaan investor kepada ANTAM akan mendorong terciptanya kerja sama untuk membangun smelter, sedangkan dukungan pemerintah akan mempercepat dalam proses ijin dan komunikasi dengan masyarakat dimana tempat smelter tersebut akan dibangun. Sedangkan untuk ancaman yang mempunyai bobot paling tinggi adalah terbatasnya pinjaman dana untuk pengembangan dan harga nikel belum stabil, hal ini disebabkan karena kondisi keuangan perusahaan yang terbatas sehingga akan menghambat dalam proses pengembangan pembangunan smelter, kedua harga nikel yang tidak stabil, karena ANTAM masih mengandalkan komoditas nikel untuk pendapatan perusahaannya. Skor dari pengaruh faktor eksternal adalah 3.01.

Untuk matriks IFAS, menekankan pada area fungsional bisnis termasuk manajemen, pemasaran, keuangan/ akutansi, produksi, penelitian dan pengembangan, system informasi manajemen, hubungan antar area bisnis (Sapratama, 2016), yang disarikan seperti dalam Tabel 2. Berdasarkan Tabel 2, bobot yang paling tinggi untuk kekuatan adalah Penyertaan Modal Negara dan 
Biaya Operasional Nikel kedua paling rendah secara Global, hal ini disebabkan karena ANTAM sebagai perusahaan BUMN, dengan negara memiliki saham seri B $65 \%$, sehingga negara akan menyertakan modal disaat perusahaan membutuhkan, Biaya Operasional Nikel kedua terendah Global, kekuatan yang dapat meningkatkan margin profit untuk ANTAM disaat harga tinggi, dan disaat harga rendah ANTAM dapat bertahan. Sedangkan untuk kelemahan dengan bobot tertinggi adalah keterbatasan keuangan perusahaan dan ANTAM tidak dapat mengontrol harga jual komoditas, kedua kelemahan tersebut dapat mengakibatkan gagalnya proses hilirisasi berjalan dengan cepat dan baik. Skor untuk pengaruh internal adalah 2.73.

\section{Matriks Profil Kompetitif}

Dalam dunia usaha, pengetahuan tentang kemampuan dan posisi perusahaan/organisasi adalah penting. Pengetahuan ini diperoleh dari pihak internal maupun eksternal perusahaan. Pengetahuan tersebut dapat berupa informasi tentang apa yang dibutuhkan pelanggan, kapasitas mesin pabrik, keadaan jaringan pemasaran, komposisi sales representative, keadaan jaringan pemasok, hal-hal yang akan dilakukan oleh para pesaing, serta peluang-peluang yang mungkin ada. Apabila pengetahuan yang dimiliki dapat dikelola dengan baik dan efektif, maka keunggulan kompetitif perusahaan dapat dicapai dengan mudah. Berikut ini adalah matriks Profil Kompetitif untuk posisi ANTAM terhadap perusahaan lain dengan berdasarkan 3 komoditas utama. Bila dilihat dari Tabel 3 untuk komoditas emas, terlihat bahwa ANTAM hanya unggul dalam pabrik untuk Pengolahan dan Pemurnian Emas untuk faktor lainnya masih kalah dibanding perusahaan lainnya. Komoditas Nikel dapat dilihat pada Tabel 4, terlihat ANTAM masih bisa bersaing dengan kelebihan pada cadangan yang besar serta mempunyai IUP Nikel yang banyak sedangkan pesaingnya menang di kapasitas produksi pabrik hilirisasi.Untuk komoditas Bauksit pada Tabel 5, ANTAM unggul tipis atas pesaing utamanya yaitu PT. Harita Prima Abadi Mineral terkait dengan cadangan dan banyaknya IUP.

Tabel 1. Evaluasi Faktor Eksternal

\begin{tabular}{|c|c|c|c|}
\hline Faktor-faktor Eksternal Utama Peluang & Bobot & Peringkat & Skor \\
\hline Berdirinya pabrik smelter dalam negeri & 0,08 & 4 & 0,32 \\
\hline Pembentukan Holding Pertambangan & 0,01 & 4 & 0,04 \\
\hline Permintaan masyarakat dalam negeri maupun luar negeri terhadap emas tinggi & 0,01 & 2 & 0,02 \\
\hline Kepercayaan Investor Ke Brand Antam & 0,15 & 4 & 0,6 \\
\hline Dukungan pemerintah untuk hilirisasi industry pertambangan & 0,08 & 4 & 0,32 \\
\hline Perkembangan teknologi pengolahan mineral yang semakin murah & 0,03 & 3 & 0,09 \\
\hline Tumbuhnya industry otomatif berbasis baterai global & 0,03 & 3 & 0,09 \\
\hline Diberlakukannya UU Minerba No. 4 Tahun 2009 & 0,01 & 2 & 0,02 \\
\hline Pembangunan Infrastruktur dan pengembangan industry dalam negeri & 0,01 & 2 & 0,02 \\
\hline Kebutuhan rare earth element dunia & 0,01 & 3 & 0,03 \\
\hline Adanya akreditasi internasional & 0,02 & 4 & 0,08 \\
\hline Kerjasama dengan dunia pendidikan & 0,02 & 2 & 0,04 \\
\hline Faktor-faktor Eksternal Utama Ancaman & Bobot & Peringkat & Skor \\
\hline Masuknya pendatang baru baik bisnis nikel, emas dan bauksit asing maupun lokal & 0,01 & 1 & 0,01 \\
\hline Dihentikannya program relaksasi nikel/Larangan Ekspor Bijih Nikel & 0,1 & 2 & 0,2 \\
\hline Harga nikel yang belum stabil & 0,12 & 2 & 0,24 \\
\hline Melemahnya perekonomian global & 0,02 & 2 & 0,04 \\
\hline Terbatasnya pinjaman dana untuk pengembangan & 0,12 & 3 & 0,36 \\
\hline Jatuh tempo pembayaran obligasi perusahaan & 0,1 & 3 & 0,3 \\
\hline Regulasi untuk mendapatkan IUP baru & 0,03 & 3 & 0,09 \\
\hline Sulitnya untuk mendapatkan lahan baru & 0,01 & 3 & 0,03 \\
\hline Penambangan emas tanpa ijin, serta penerimaan masyarakat & 0,01 & 3 & 0,03 \\
\hline Kepastian hukum daerah maupun pusat & 0,01 & 2 & 0,02 \\
\hline Perizinan kehutanan & 0,01 & 2 & 0,02 \\
\hline Jumlah Bobot & 1 & & 3,01 \\
\hline
\end{tabular}


Tabel 2. Evaluasi faktor internal

\begin{tabular}{lccc}
\hline Faktor-faktor Internal Utama Kekuatan & Bobot & Peringkat & Skor \\
\hline Penyertaan Modal Negara (PMN) untuk kebutuhan pengembangan & 0,1 & 3 & 0,3 \\
Mempunyai cadangan nikel terbesar global & 0,08 & 4 & 0,32 \\
Mempunyai cadangan bauksit terbesar global & 0,08 & 4 & 0,32 \\
Diversifikasi Komoditi dan Produk & 0,02 & 4 & 0,08 \\
Biaya Operasional Nikel kedua paling rendah & 0,09 & 4 & 0,36 \\
Reputasi pertambangan dan pengolahan yang baik & 0,05 & 3 & 0,15 \\
Kompetensi Inti Pertambangan yang terintegrasi mulai dari Eksplorasi sampai pengolahan & 0,08 & 3 & 0,24 \\
Perusahaan BUMN pertambangan dengan asset terbesar & 0,08 & 4 & 0,32 \\
Mempunyai pabrik pengolahan dan pemurnian emas akreditasi LBMA & 0,02 & 4 & 0,08 \\
Mempunyai smelter nikel dan bauksit & 0,02 & 4 & 0,08 \\
Perusahaan pertama di Indonesia yang mengeluarkan produk emas batangan & 0,01 & 3 & 0,03 \\
\hline Faktor-faktor Internal Utama Kelemahan & Bobot & Peringkat & Skor \\
\hline Antam tidak bisa mengontrol harga jual & 0,07 & 1 & 0,07 \\
Keterbatasan keuangan Perusahaan dalam pendanaan pengembangan hilirisasi & 0,08 & 1 & 0,08 \\
tingkat hutang atau pinjaman Perusahaan yang cukup tinggi & 0,06 & 1 & 0,06 \\
kinerja keuangan Anak Perusahaan belum memberikan return & 0,02 & 2 & 0,04 \\
keterbatasan dalam pengambilan keputusan yang cepat (birokratis) & 0,04 & 1 & 0,04 \\
Kapasitas pabrik yang masih terbatas dan teknologi lama & 0,03 & 2 & 0,06 \\
Penerapan industry 4.0 belum maksimal & 0,02 & 2 & 0,04 \\
Struktur organisasi belum efektif dan sesuai dengan strategi & 0,01 & 2 & 0,02 \\
Cadangan emas yang menipis & 0,03 & 1 & 0,03 \\
Research and Development belum maksimal & 0,01 & 1 & 0,01 \\
\hline Jumlah Bobot & 1 & Total & 2,73 \\
& & Skor & \\
\hline
\end{tabular}

Tabel 3. Matriks profil kompetitif komoditas Emas

\begin{tabular}{|c|c|c|c|c|c|c|c|c|c|c|c|c|}
\hline \multirow{2}{*}{ Faktor-faktor keberhasilan } & \multicolumn{3}{|c|}{ Freeport Indonesia } & \multicolumn{3}{|c|}{ Merdeka Copper Gold } & \multicolumn{3}{|c|}{ Agincort } & \multicolumn{3}{|c|}{ Antam } \\
\hline & Bobot & Peringkat & Skor & Bobot & Peringkat & Skor & Bobot & Peringkat & Skor & Bobot & Peringkat & Skor \\
\hline $\begin{array}{l}\text { Mempunyai Pabrik Pemurnian } \\
\text { dan Pengolahan (LBMA) }\end{array}$ & 0,2 & 1 & 0,2 & 0,2 & 1 & 0,2 & 0,2 & 1 & 0,2 & 0,2 & 4 & 0,8 \\
\hline $\begin{array}{l}\text { Mempunyai Tambang/IUP } \\
\text { Emas }\end{array}$ & 0,1 & 4 & 0,4 & 0,1 & 4 & 0,4 & 0,1 & 4 & 0,4 & 0,1 & 4 & 0,4 \\
\hline Cadangan Emas yang besar & 0,1 & 4 & 0,4 & 0,1 & 4 & 0,4 & 0,1 & 3 & 0,3 & 0,1 & 1 & 0,1 \\
\hline Kapasitas Produksi Tambang & 0,1 & 4 & 0,4 & 0,1 & 2 & 0,2 & 0,1 & 2 & 0,2 & 0,1 & 1 & 0,1 \\
\hline Kapasitas Produksi Pabrik & 0,1 & 1 & 0,1 & 0,1 & 2 & 0,2 & 0,1 & 1 & 0,1 & 0,1 & 2 & 0,2 \\
\hline Mempunyai Tim Eksplorasi & 0,05 & 4 & 0,2 & 0,05 & 4 & 0,2 & 0,05 & 4 & 0,2 & 0,05 & 3 & 0,15 \\
\hline Infrastruktur & 0,01 & 4 & 0,04 & 0,01 & 2 & 0,02 & 0,01 & 1 & 0,01 & 0,01 & 2 & 0,02 \\
\hline Posisi Keuangan & 0,1 & 4 & 0,4 & 0,1 & 2 & 0,2 & 0,1 & 3 & 0,3 & 0,1 & 1 & 0,1 \\
\hline SDM & 0,04 & 4 & 0,16 & 0,04 & 3 & 0,12 & 0,04 & 3 & 0,12 & 0,04 & 2 & 0,08 \\
\hline Management & 0,05 & 4 & 0,2 & 0,05 & 3 & 0,15 & 0,05 & 3 & 0,15 & 0,05 & 3 & 0,15 \\
\hline Ekspansi Global & 0,1 & 4 & 0,4 & 0,1 & 2 & 0,2 & 0,1 & 3 & 0,3 & 0,1 & 1 & 0,1 \\
\hline \multirow[t]{2}{*}{ Teknologi 4.0} & 0,05 & 4 & 0,2 & 0,05 & 2 & 0,1 & 0,05 & 3 & 0,15 & 0,05 & 2 & 0,1 \\
\hline & 1 & & 3,1 & 1 & & 2,39 & 1 & & 2,43 & 1 & & 2,3 \\
\hline
\end{tabular}


Tabel 4. Matriks profil kompetitif komoditas Nikel

\begin{tabular}{|c|c|c|c|c|c|c|c|c|c|c|c|c|}
\hline \multirow[t]{2}{*}{ Faktor-faktor keberhasilan } & \multicolumn{3}{|c|}{ Freeport Indonesia } & \multicolumn{3}{|c|}{ Merdeka Copper Gold } & \multicolumn{3}{|c|}{ Agincort } & \multicolumn{3}{|c|}{ Antam } \\
\hline & Bobot & Peringkat & Skor & Bobot & Peringkat & Skor & Bobot & Peringkat & Skor & Bobot & Peringkat & Skor \\
\hline Mempunyai Smelter & 0,2 & 4 & 0,8 & 0,2 & 4 & 0,8 & 0,2 & 4 & 0,8 & 0,2 & 4 & 0,8 \\
\hline $\begin{array}{l}\text { Mempunyai Tambang/IUP } \\
\text { Nikel }\end{array}$ & 0,1 & 1 & 0,1 & 0,1 & 3 & 0,3 & 0,1 & 1 & 0,1 & 0,1 & 4 & 0,4 \\
\hline Cadangan Nikel yang besar & 0,1 & 1 & 0,1 & 0,1 & 3 & 0,3 & 0,1 & 1 & 0,1 & 0,1 & 4 & 0,4 \\
\hline Kapasitas Produksi Pabrik & 0,1 & 4 & 0,4 & 0,1 & 3 & 0,3 & 0,1 & 4 & 0,4 & 0,1 & 2 & 0,2 \\
\hline Kapasitas Produksi Tambang & 0,1 & 1 & 0,1 & 0,1 & 3 & 0,3 & 0,1 & 1 & 0,1 & 0,1 & 4 & 0,4 \\
\hline Mempunyai Tim Eksplorasi & 0,05 & 1 & 0,05 & 0,05 & 3 & 0,15 & 0,05 & 1 & 0,05 & 0,05 & 4 & 0,2 \\
\hline Infrastruktur & 0,01 & 4 & 0,04 & 0,01 & 3 & 0,03 & 0,01 & 2 & 0,02 & 0,01 & 2 & 0,02 \\
\hline Posisi Keuangan & 0,1 & 4 & 0,4 & 0,1 & 2 & 0,2 & 0,1 & 2 & 0,2 & 0,1 & 2 & 0,2 \\
\hline SDM & 0,04 & 3 & 0,12 & 0,04 & 3 & 0,12 & 0,04 & 3 & 0,12 & 0,04 & 4 & 0,16 \\
\hline Management & 0,05 & 4 & 0,2 & 0,05 & 3 & 0,15 & 0,05 & 2 & 0,1 & 0,05 & 2 & 0,1 \\
\hline Ekspansi Global & 0,1 & 4 & 0,4 & 0,1 & 4 & 0,4 & 0,1 & 4 & 0,4 & 0,1 & 2 & 0,2 \\
\hline \multirow[t]{2}{*}{ Teknologi 4.0} & 0,05 & 4 & 0,2 & 0,05 & 4 & 0,2 & 0,05 & 4 & 0,2 & 0,05 & 2 & 0,1 \\
\hline & 1 & & 2,91 & 1 & & 3,25 & 1 & & 2,59 & 1 & & 3,18 \\
\hline
\end{tabular}

Tabel 4. Matriks profil kompetitif komoditas Bauksit

\begin{tabular}{lcccccccccccc}
\hline Faktor-faktor keberhasilan & \multicolumn{3}{c}{ Freeport Indonesia } & \multicolumn{3}{c}{ Merdeka Copper Gold } & \multicolumn{3}{c}{ Agincort } & \multicolumn{3}{c}{ Antam } \\
\cline { 2 - 13 } & Bobot & Peringkat & Skor & Bobot & Peringkat & Skor & Bobot & Peringkat & Skor & Bobot & Peringkat & Skor \\
\hline Mempunyai Smelter & 0,2 & 4 & 0,8 & 0,2 & 1 & 0,2 & 0,2 & 1 & 0,2 & 0,2 & 4 & 0,8 \\
Mempunyai Tambang/IUP & 0,1 & 3 & 0,3 & 0,1 & 3 & 0,3 & 0,1 & 3 & 0,3 & 0,1 & 4 & 0,4 \\
Cadangan Bauksit yang besar & 0,1 & 3 & 0,3 & 0,1 & 4 & 0,4 & 0,1 & 3 & 0,3 & 0,1 & 4 & 0,4 \\
Kapasitas Produksi Tambang & 0,1 & 3 & 0,3 & 0,1 & 2 & 0,2 & 0,1 & 2 & 0,2 & 0,1 & 3 & 0,3 \\
Kapasitas Produksi Pabrik & 0,1 & 3 & 0,3 & 0,1 & 2 & 0,2 & 0,1 & 1 & 0,1 & 0,1 & 2 & 0,2 \\
Mempunyai Tim Eksplorasi & 0,05 & 3 & 0,15 & 0,05 & 3 & 0,15 & 0,05 & 2 & 0,1 & 0,05 & 4 & 0,2 \\
Infrastruktur & 0,01 & 3 & 0,03 & 0,01 & 2 & 0,02 & 0,01 & 1 & 0,01 & 0,01 & 2 & 0,02 \\
Posisi Keuangan & 0,1 & 3 & 0,3 & 0,1 & 2 & 0,2 & 0,1 & 3 & 0,3 & 0,1 & 2 & 0,2 \\
SDM & 0,04 & 2 & 0,08 & 0,04 & 2 & 0,08 & 0,04 & 2 & 0,08 & 0,04 & 3 & 0,12 \\
Management & 0,05 & 3 & 0,15 & 0,05 & 3 & 0,15 & 0,05 & 3 & 0,15 & 0,05 & 2 & 0,1 \\
Ekspansi Global & 0,1 & 2 & 0,2 & 0,1 & 2 & 0,2 & 0,1 & 3 & 0,3 & 0,1 & 2 & 0,2 \\
Teknologi 4.0 & 0,05 & 2 & 0,1 & 0,05 & 2 & 0,1 & 0,05 & 3 & 0,15 & 0,05 & 2 & 0,1 \\
\hline & 1 & & 3,01 & 1 & & 2,20 & 1 & & 2,19 & 1 & & 3,04 \\
\hline
\end{tabular}

\section{Tahap Pencocokan}

Strategi sering kali didefinisikan sebagai pencocokan yang dibuat suatu organisasi antara sumber daya dan keterampilan internalnya serta peluang dan risiko yang diciptakan oleh faktor-faktor eksternal (David, 2011). Tahap pencocokan dari kerangka perumusan strategi urutannya sebagai berikut: Matriks SWOT, Matriks SPACE, Matriks BCG, Matriks IE dan Matriks Strategi Besar. Penggunaan matriks tersebut untuk melihat korelasi antara matriks, sehingga akan diperoleh suatu pilihan strategi yang tepat dilihat dari berbagai macam alat bantu tersebut.

\section{Matriks SWOT}

Kolom vertikal berisi External Factor Analysis Summary (EFAS), dan Baris horizontal berisi Internal Factor Analysis Summary (IFAS). Sebuah alat pencocokan yang penting yang membantu manajer mengembangkan empat jenis strategi (David, 2011), yaitu Pada sel StrengthsOppurtunities (SO) diprogramkan strategi memanfaatkan peluang berkembang dengan menggunakan kekuatan yang ada; Pada sel Weakness-Oppurtunities (WO) diprogramkan strategi memanfaatkan peluang berkembang dengan mengatasi kelemahan internal; Pada sel Strengths-Threats (ST) disusun stategi memanfaatkan kekuatan untuk menghindari ancaman; Pada sel WeaknessThreats (WT) dibangun stategi memperkecil kelemahan dan pada saat yang sama menghindari ancaman eksternal. Hasil yang diperoleh dapat dilihat pada Tabel 5. 
Tabel 5. Matriks SWOT

\begin{tabular}{|c|c|c|}
\hline & Kekuatan & Kelemahan \\
\hline Peluang & $\begin{array}{l}\text { Strategi S-O } \\
\text { Menjual Ore Nikel/Bauksit Dalam Negeri } \\
\text { Penyertaan modal holding untuk hilirisasi } \\
\text { Mengembangkan pabrik hilirisasi emas dan } \\
\text { Diversifikasi Emas } \\
\text { Penyertaan Modal Untuk Hilirisasi } \\
\text { PMN Untuk hilirisasi } \\
\text { Membuat Litbang yang kuat } \\
\text { Membuat Pabrik Baterai } \\
\text { Mengembangkan pabrik hilirisasi nikel stainless steel } \\
\text { Mencari element dari tambang nikel dan bauksit } \\
\text { Diversifikasi produk emas } \\
\text { Membuat kajian hilirisasi termurah dan tercepat } \\
\text { pembangunannya }\end{array}$ & $\begin{array}{l}\text { Strategi W- O } \\
\text { Menjual Ore Nikel/Bauksit dalam negeri } \\
\text { Penyertaan Modal Akuisisi Emas Holding } \\
\text { Intensif Eksplorasi Emas atau akuisisi } \\
\text { Peningkatan kerjasama horizontal atau vertikal ke } \\
\text { depan dan belakang pembangunan smelter } \\
\text { Mengembangkan hilirisasi dengan biaya rendah } \\
\text { Integrasi ke depan } \\
\text { Memperloh IUP dan Akusisi Pemilik IUP }\end{array}$ \\
\hline Ancaman & $\begin{array}{l}\text { Strategi S-T } \\
\text { Menjalin kerjasama horizontal } \\
\text { Mempercepat hilirisasi } \\
\text { Memakai ore untuk pabrik sendiri } \\
\text { Menurunkan harga cast cost } \\
\text { Kerjasama vetikal dan horizontal } \\
\text { Meminta dukungan pemerintah } \\
\text { Meminta dukungan pemerintah } \\
\text { Reformasi Agraria } \\
\text { Meminta pemerintah untuk tegas } \\
\text { Pelaksanaan UU yang baru } \\
\text { Koordinasi dengan Kementrian Kehutanan }\end{array}$ & $\begin{array}{l}\text { Strategi W-T } \\
\text { Menjual Ore Nikel/Bauksit dalam negeri } \\
\text { Menjual Ore Nikel/Bauksit dalam negeri } \\
\text { Memanfaatkan teknologi } 4.0 \text { untuk efisiensi } \\
\text { operasional } \\
\text { Memanfaatkan teknologi } 4.0 \text { untuk efisiensi } \\
\text { operasional } \\
\text { Divestasi Anak Perusahaan } \\
\text { Meminta dukungan pemerintah }\end{array}$ \\
\hline
\end{tabular}

\section{Matriks Strategic Position and Action Evaluation (SPACE)}

Matriks Posisi Strategis dan Evaluasi Tindakan atau Strategic Position and Action Evaluation (SPACE). Matriks ini merupakan kerangka empat kuadran yang menunjukan apakah strategi agresif, konservatif, defensive, atau kompetitif yang paling sesuai untuk suatu organisasi tertentu. Sumbu-sumbu matriks SPACE menunjukan dua dimensi internal yaitu Financial Strength (FS) dan Competitive Advantage (CA) dan dua dimensi eksternal yaitu Enviroment Stability (ES) dan Industry Strength (IS) (David, 2011). Berdasarkan Tabel 6 kemudian digambarkan kuadran dari ANTAM dalam matriks SPACE seperti terlihat hasilnya pada Gambar 5. Dari hasil pengeplotan terhadap matriks SPACE, Posisi ANTAM berada pada kuadran I, artinya ANTAM berada dalam posisi agresif sehingga strategi yang harus dikembangkan adalah: Integrasi ke belakang, Integrasi ke depan, Penetrasi Pasar, Pengembagan Pasar, Pengembangan Produk, dan Diversifikasi.

\section{Matriks Boston Consulting Group (BCG)}

Berdasarkan data-data market share dan growth rate dari setiap produk ANTAM, kemudian diplotkan dalam matriks BCG, hasilnya dapat dilihat pada Gambar 6 . Berdasarkan Gambar 6, terlihat produk Antam banyak terdapat di kuadran Dogs, yaitu Feronickel, Emas, Perak, Batubara dan Alumina. Artinya, produk dalam kategori Dogs ini umumnya merupakan beban bagi perusahaan karena dapat menguras waktu manajemen dan sebagian besar sumber daya perusahaan. Unit bisnis atau produk yang telah berada pada kategori ini biasanya akan mengalami pengurangan, divestasi ataupun likuidasi oleh manajemen perusahaan. Tetapi untuk kasus ANTAM produk ini masih mengalami pertumbuhan dan diharuskan dalam tahap pengembangan Pabrik. Sedangkan untuk Cash Cows terdapat dua produk, yaitu Bijih Nikel dan Bijih Bauksit, dalam kategori Cash Cows ini produk atau unit bisnis yang merupakan pemimpin pasar, menghasilkan uang atau pendapatan yang lebih banyak dibandingkan dengan biaya yang dikeluarkan oleh perusahaannya. Produk atau unit 
bisnis pada kategori ini memiliki pangsa pasar yang tinggi namun prospek pertumbuhan kedepan akan sangat terbatas. Pendapatan yang didapat pada tingkat Cash Cows ini biasanya digunakan sebagai pendanaan untuk penelitian dan pengembangan produk-produk baru yang masih berada di kategori Question Marks. Kondisi ini juga digunakan untuk membayar hutanghutang perusahaan serta membayar dividen kepada pemegang saham. Perusahaan disarankan untuk tetap berinvestasi pada produk-produk dalam kategori Cash Cows ini untuk mempertahankan produktivitas dan kualitas atau dapat juga dijadikan pendapatan pasif bagi perusahaan.

\section{Matriks Internal Eksternal}

Berdasarkan skor EFAS dan IFAS pada Tabel 1 dan Tabel 2, kemudian dilakukan pengeplotan posisi untuk matriks Internal Eksternal dapat dilihat pada Gambar 7. Dengan posisi matriks internal dan eksternal pada kuadran IV, maka kondisi perusahaan dalam posisi tumbuh dan membangun intensif dan integratif. Berikut adalah contoh-contoh dari implementasi yang dilakukan oleh ANTAM terkait dengan strategi pada kuadran IV ini, seperti Pembangunan Smelter Grade Alumina Refinery (SGAR) yang sedang dalam konstruksi di Mempawah Kalimantan Barat, pembangunan ini untuk mengintegrasikan surplus di sumberdaya bauksit yang ada di daerah tersebut. Pembangunan ini juga bekerja sama dengan PT. Inalum (Persero) Tbk untuk menampung produk Alumina yang dihasilkan sebagai bahan baku pembuatan Almunium, kemudian Pembangunan FENI Haltim untuk menghasilkan Ferronickel untuk menyerap sumberdaya nikel yang ada di Maluku Utara.AM berada di Kuadran IV

Tabel 6. Matriks Posisi Strategis dan Evaluasi Tindakan

\begin{tabular}{|c|c|c|c|c|c|c|c|}
\hline \multicolumn{4}{|c|}{ Posisi Strategis Internal } & \multicolumn{4}{|c|}{ Posisi Strategis Eksternal } \\
\hline \multicolumn{2}{|c|}{ Finacial Strength (FS) } & \multicolumn{2}{|c|}{ Competitive Advantage (CA) } & \multicolumn{2}{|c|}{ Enviroment Stability (ES) } & \multicolumn{2}{|c|}{ Industrial Strength (IS) } \\
\hline Parameter & Skor & Parameter & Skor & Parameter & Skor & Parameter & Skor \\
\hline $\begin{array}{l}\text { Pengembalian Atas } \\
\text { Investasi }\end{array}$ & 2 & Pangsa Pasar Emas & -1 & Perubahan teknologi & -3 & Tekanan Kompetitif & 1 \\
\hline Pengungkit & 2 & Pangsa Pasar Nikel & -1 & $\begin{array}{l}\text { Pertumbuhan Ekonomi } \\
\text { Global }\end{array}$ & -2 & Potensi Pertumbuhan & 4 \\
\hline Likuiditas & 3 & Pangsa Pasar Bauksit & -1 & Variabilitas harga nikel & -2 & Potensi Laba & 4 \\
\hline Modal Kerja & 3 & $\begin{array}{l}\text { Kualitas Produk Emas } \\
\text { (Kesesuaian Kadar) }\end{array}$ & -1 & Variabilitas harga emas & -5 & $\begin{array}{l}\text { Stabilitas Harga } \\
\text { Komoditi }\end{array}$ & 3 \\
\hline Arus Kas & 3 & $\begin{array}{l}\text { Kualitas Produk Nikel } \\
\text { (Kesesuaian Kadar) }\end{array}$ & -3 & Variabilitas harga bauksit & -2 & Stabilitas Keuangan & 3 \\
\hline Perputaran Persediaan & 3 & $\begin{array}{l}\text { Kualitas Produk Bauksit } \\
\text { (Kesesuaian Kadar) }\end{array}$ & -3 & $\begin{array}{l}\text { Peraturan Pemerintah } \\
\text { ESDM }\end{array}$ & -3 & Trik-trik teknologis & 3 \\
\hline Laba per Saham & 3 & Kebutuhan Energi & -2 & $\begin{array}{l}\text { Peraturan Pemerintah } \\
\text { Kehutanan }\end{array}$ & -3 & Utilisasi Sumberdaya & 3 \\
\hline Rasio Harga/Laba & 3 & Integrasi Vertikal & -2 & $\begin{array}{l}\text { Peraturan Pemerintah } \\
\text { Pajak }\end{array}$ & -3 & $\begin{array}{l}\text { Kemudahan masuk } \\
\text { pasar }\end{array}$ & 2 \\
\hline \multirow[t]{11}{*}{ Rata-rata } & 2.75 & $\begin{array}{l}\text { Penguasaan Cadangan } \\
\text { Nikel }\end{array}$ & -1 & $\begin{array}{l}\text { Peraturan Pemerintah } \\
\text { Daerah }\end{array}$ & -1 & $\begin{array}{l}\text { Konsumen Barang/ } \\
\text { Jasa }\end{array}$ & 4 \\
\hline & & $\begin{array}{l}\text { Penguasaan Cadangan } \\
\text { Bauksti }\end{array}$ & -1 & Tekanan kompetitif & -2 & Rata-rata & 3.00 \\
\hline & & $\begin{array}{l}\text { Penguasaan Cadangan } \\
\text { Emas }\end{array}$ & -5 & Kemudahan ke luar pasar & -4 & & \\
\hline & & Smelter Emas & -3 & Risiko Bisnis & -1 & & \\
\hline & & Smelter Nikel & -3 & Rata-rata & -2.58 & & \\
\hline & & Smelter Bauksit & -2 & & & & \\
\hline & & Eksplorasi & -3 & & & & \\
\hline & & Multi Komoditi & -1 & & & & \\
\hline & & Trik-trik teknologi & -3 & & & & \\
\hline & & $\begin{array}{l}\text { Kendali atas pemasok } \\
\text { dan distributor }\end{array}$ & -2 & & & & \\
\hline & & Rata-rata & -2.11 & & & & \\
\hline
\end{tabular}




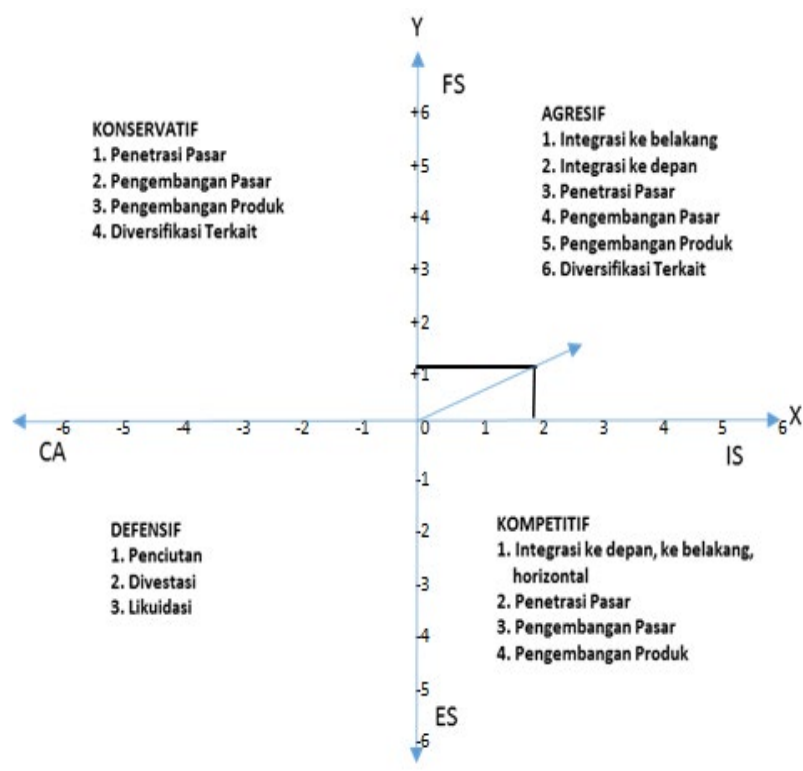

Gambar 5. Kuadran Matriks SPACE ANTAM

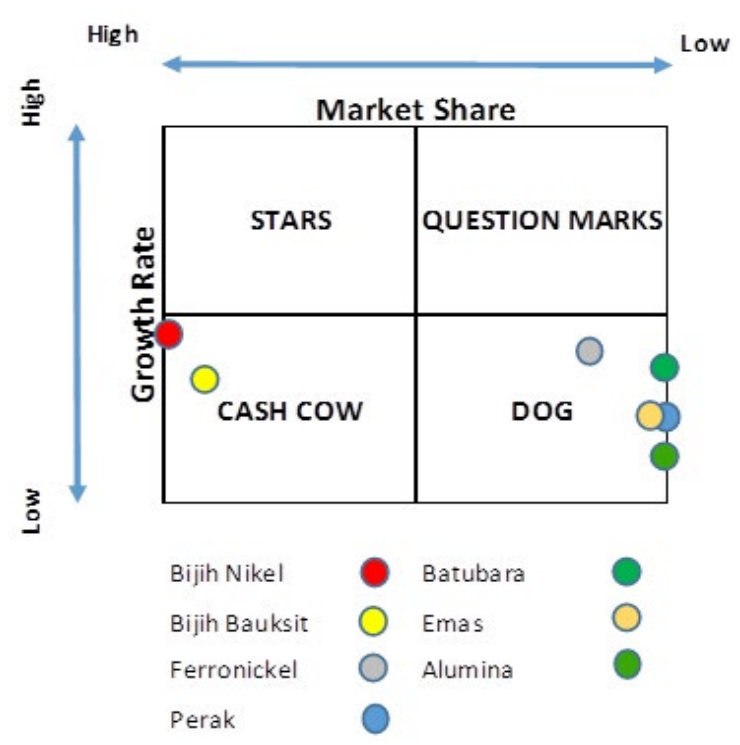

Gambar 6. Matriks BCG Produk ANTAM

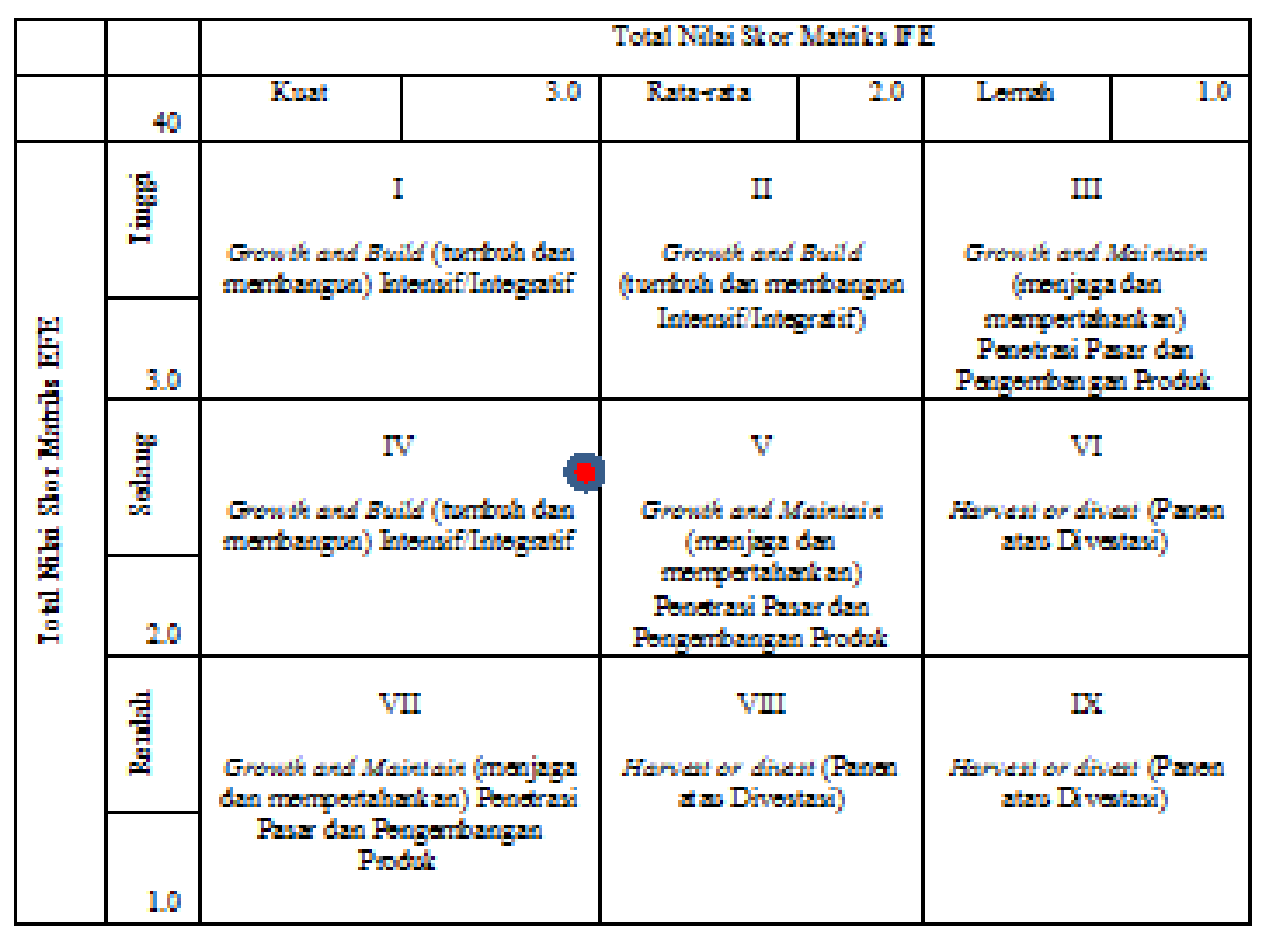

Gambar 7. Matriks IE ANTAM berada di Kuadran IV

\section{Matriks Grand Strategy}

Hasil EFAS dan IFAS, diplotkan juga di Matriks Grand Strategy dengan mengacu untuk sumbu $x$ terkait dengan posisi kompetitif yang kuat dan sumbu y terkait dengan pasar yang tumbuh dengan cepat. Setelah dilakukan pengeplotan, diperoleh grafik dan kuadran posisi dari Antam seperti terlihat pada Gambar 8. Dengan posisi yang ada di kuadran I, maka strategi yang cocok untuk
ANTAM adalah sebagai berikut: Pengembangan Pasar, Penetrasi Pasar, Pengembangan Produk, Integrasi ke depan, Integrasi ke belakang, Integrasi horizontal, dan Diversifikasi Terkait. Strategi Pengembangan Pasar ANTAM, yaitu dengan memperbanyak butik emas di seluruh Indonesia, saat ini masih di ibu kota propinsi besar, seperti Bandung, Surabaya, Makasar, Medan dan lainnya. Penetrasi Pasar, untuk komoditas emas ANTAM telah mengeksport ke Jepang dengan bekerja 
sama dengan distributor Jepang. Integrasi ke depan, ANTAM bekerja sama dengan PT. POS Indonesia untuk mendistribusikan produk emas batangannya.

\section{Tahap Pemilihan Strategi}

Matriks Perencanaan Strategis Kuantitatif (Quantitative Strategic Palnning Matrix-QSPM). QSPM menggunakan analisi input dari Tahap 1 dan hasil pencocokan dari analisis Tahap 2 untuk secara obyektif menentukan strategi yang akan dijalankan diantara strategi-strategi alternatif (David, 2011). QSPM merupakan alat analisis yang digunakan untuk memutuskan strategi yang akan digunakan berdasarkan dari kemenarikan alternatif-alternatif strategi yang ada. Perhitungan QSPM didasarkan kepada input dari bobot matriks internal ekternal, serta alaternatif strategi pada tahap pencocokan.
Urutan strategi prioritas berdasarkan hasil matriks QSPM adalah sebagai berikut: Pembangunan Pabrik Ferronickel dengan cara biaya sendiri atau bekerja sama dengan pesaing maupun pendatang baru yang mempunyai modal besar (6,96), Memperbanyak koordinasi dengan kementrian terkait untuk mendapatkan hubungan atau kemudahan-kemudahan sebagai perusahaan milik negara $(6,83)$, Pembangunan Pabrik Alumina dengan biaya sendiri atau bekerja sama dengan pesaing maupun pendatang baru $(6,49)$, Membangun Pabrik Batere $(6,17)$, Intensifikasi Riset and Development $(5,57)$, Akuisisi Tambang Emas $(5,4)$, Membangun/menambah kapasitas Pengolahan dan Pemurnian Emas $(5,36)$, Membangun Pabrik Stainless Steel (5,36), Pengembangan Produk Emas/ Manufacture (5,33), Divestasi Anak Perusahaan $(4,52)$, dan Intensifikasi Eksplorasi Emas (4,23).

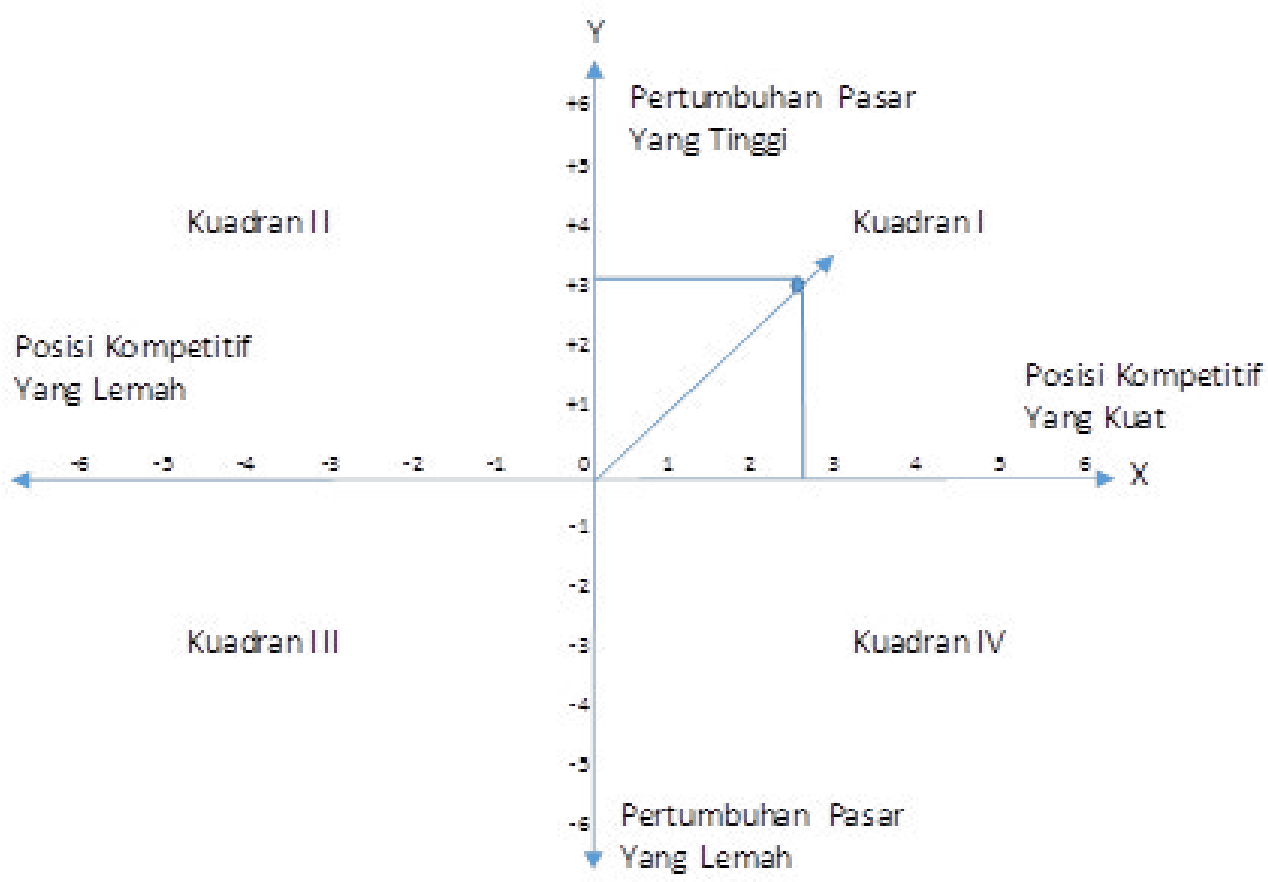

Gambar 8. Matriks Grand Strategy ANTAM berada di Kuadran I 


\section{Implikasi Manajerial}

Penelitian ini menghasilkan beberapa temuan yang selanjutnya disusun menjadi implikasi manajerial yang sepenuhnya diserahkan kepadaANTAM dan Pemerintah dalam membuat kebijakan terkait upaya meningkatkan kinerja baik itu keuangan maupun produksi. Saat ini Strategi ANTAM yaitu Integrasi Horizontal, Integrasi Vertikal, Integrasi kebelakang dan Integrasi Kedepan dalam mencapai tujuan hilirisasi. Adapun kendala yang dihadapi oleh ANTAM terkait strategi tersebut lebih disebabkan karena: 1) Budaya dan kebijakan strategi ANTAM yang tidak mengakomodir untuk kelincahan organisasi seperti kebijakan yang ada di Business Development, SCM dan GCG, sesuai dengan (Wijaya, 2017) bahwa Budaya perusahaan sangat berpengaruh terhadap strategi perusahaan begitu juga sebaliknya. Terkait dengan budaya juga, menurut Lamsihar (2019) manajemen perubahan dalam implementasi strategi cukup memegang peran penting; 2) Tidak fokusnya prioritas hilirisasi terlihat dari pembangunan pabrik yang secara bersamaan; 3) Project Management terkait dengan project pembangunan pabrik Ferronickel belum sepenuhnya dikuasai; 4) Kemampuan SDM yang menguasai pembangunan Pabrik terbatas dengan Project Pengembangan Pabrik yang bersamaan; 5) Faktor kesulitan keuangan dikarenakan kerugian ANTAM pada tahun 2014 dan 2015; 6) Divisi Corporate Strategic perlu menganalisis kelincahan organisasi, dengan dilakukannya pengecekan terhadap kebijakan yang menghambat kecepatan dan rendahnya performance; 7) Perlu dilakukan restrukstrurisasi organisasi agar lebih futuristic yang berdasarkan pada fungsi terkait dengan perubahan situasi persaingan serta globalisasi area operasi; 8) Perlu dilakukan perubahan Long Term Vision ANTAM, karena visi yang ada sekarang tidak terlihat konkrit untuk melihat kondisi ANTAM untuk tahun 2030. Sehingga Visi tersebut tidak menjadi guide dalam penentuan prioritas pengembangan pabrik. Sesuai yang disampaikan oleh Niven (2002), yaitu Visi harus kongkrit untuk menjadi apa dimasa depan; 9) Pemerintah Indonesia tidak hanya mendukung pembangunan Smelter untuk industri tambang saja, tetapi perlu juga merangsang industri terkait yang menggunakan produk dari smelter tersebut seperti industri baja, industri otomotif, industri kontruksi, industri elektronik untuk berkembang juga.

\section{KESIMPULAN DAN SARAN}

\section{Kesimpulan}

Hasil evaluasi strategis ANTAM dalam 5 tahun terakhir, memperlihatkan bahwa strategi yang diambil oleh ANTAM adalah agresif, tumbuh intensif dan integrative melalui integrasi ke depan, integrasi ke belakang, Integrasi horizontal, Pengembangan Pasar, Penetrasi Pasar, Pengembangan Produk, Diversifikasi terkait, sudah sesuai dengan yang dijalankan oleh ANTAM dalam kurun waktu 5 tahun terakhir. Kekurangan yang terlihat dari strategi tersebut terletak pada Long Vision ANTAM yang tidak memperlihatkan kondisi yang kongkrit, sehingga tidak mempengaruhi dalam proses perencanaan strategik berupa prioritas yang akan dikembangkan serta kebijakan strategik belum optimal dalam implementasinya sehingga agar strategi tersebut berjalan dengan baik, ANTAM perlu melakukan koreksi-koreksi kebijakan strategiknya yaitu dengan menugaskan Divisi Corporate Strategic untuk melakukan review dan mengidentifikasi terhadap kebijakan yang menghambat speed and performance perusahaan, kemudian ditindaklajuti dengan memperbaiki kebijakan tersebut, termasuk bila diperlukan merubah atau mengkoreksi SOP satuan kerja yang terkait dengan kebijakan tersebut.

\section{Saran}

Saran penelitian selanjutnya adalah melakukan penelitian pengaruh Budaya Perusahaan dan Struktur Organisasi terhadap Pelaksanaan Strategi yang ANTAM lakukan. Pengambilan data dilakukan di seluruh wilayah operasi ANTAM. Output yang diharapkan adalah formulasi dari Culture Perusahaan yang diharapkan serta Struktur Organisasi yang efektif untuk menghasilkan kebijakan strategik yang tepat.

\section{DAFTAR PUSTAKA}

Agincort R. 2018. Annual Report Agincort Resourves 2018.https:/www.agincourtresources.com/ wpcontent/uploads/2019/04/PTARAnnualReport-2018.pdf. [2020 Feb 22].

David FR. 2011. Manajemen Strategis Konsep. Jakarta: Salemba Empat.

Elyarni R, Hermanto. 2016. Analisis SWOT terhadap strategi pemasaran layanan SAP express pada PT. SAP. Jurnal Metris 17(2016): 81 - 88.

Freeport M. 2019. Annual Report Pursuant To Section 
13 Or 15(d) Of The Securities Exchange Act Of 1934. https://s22.q4cdn.com/ 529358580/files/ doc_financials/10-K/10_k2019. pdf.[2020 Feb 22].

Gozali H, Sucherly, Suryana Y, Oesman Y. 2015. The influence of corporate resources and corporate strategy to improve corporate performance at indonesian state owned enterprises. Jurnal Bisnis \& Manajemen XVI(2): 62-69.

Guntara S, Yogaswara B, Aurachman R. 2017. Strategi Transformasi PT GREENERATION INDONESIA menuju Perusahaan Ramah Lingkungan Yang Unggul dengan Pendekatan Matriks Boston Consulting Group. e-Proceeding of Engineering 4(3) Desember 2017.

Hariadi H. 2017. Analisis SWOT dalam pengelolaan sumberdaya mineral dan batubara Indonesia serta prospeknya dalam menghadapi Masyarakat Ekonomi Asean (MEA). Jurnal Teknologi Mineral dan Batubara 13(1): 73 - 90.

Hindarwati N, Yuniarti F, Yasmine. 2016. Analisis strategi bisnis pada PT Datacomm Diangraha. Jurnal Ekonomi, Manajemen dan Perbankan 2(3): 89-98.

Hunger JD, Thomas W. 1996. Strategic Management, 5th ed, New York:Addison Wesley.

Ika, Syahrir. 2017. Kebijakan hilirisasi mineral: reformasi kebijakan untuk meningkatkan penerimaan negara. Jurnal Kajian Ekonomi Keuangan 1(1):42-47.

Kinasih G, Lianto B, Suryani R. 2015. Analisis struktur industri dan perencanaan strategi bisnis PT.Herman Jaya Putra. Jurnal Ilmiah Mahasiswa Universitas Surabaya 4(1):1-19.

Kusuma C, Firdausy C. 2017. Analisis IFE, EFE, dan balance scorecard pada perusahaan PT. Kirana Megatara. Jurnal Manajemen Bisnis dan Kewirausahaan 1(1) : 147-154.

Lamsihar A, Huseini M. 2019. Transformasi budaya dan inovasi perusahaan BUMN. Inovbiz: Jurnal Inovasi Bisnis 7 (2019): 64-70.

PT. Aneka Tambang Tbk, 2014. Annual Report 2014. https://www.antam.com/en/reports/annualreports [2019 May 08]

PT. Aneka Tambang Tbk. 2015. Annual Report 2015. https://www.antam.com/en/reports/annualreports [2019 May 08]

PT. Aneka Tambang Tbk. 2016. Annual Report 2016. https://www.antam.com/en/reports/annualreports [2019 May 08]

PT. Aneka Tambang Tbk. 2017. Annual Report 2017. https://www.antam.com/en/reports/annualreports [2019 May 08]

PT. Aneka Tambang Tbk. 2018. Annual Report 2018. https://www.antam.com/en/reports/annualreports [2019 May 08]

PT. Merdeka Copper Gold Tbk. 2018. Annual Report 2018. http://www.merdekacoppergold.com/en/ investor-relation/annual-reports [2019 May 08]

PT. Vale Indonesia. 2018. Annual Report PT. Vale Indonesia 2018. http://www.vale.com/indonesia/ EN/investors/information-market-id/annualreports/doc/PT-Vale-Indonesia-Tbk-AnnualReport-2018.pdf.pdf [2019 May 08]

Maulana G, Rizaldi W, Charles A. 2019. Formulasi Sstrategi bisnis untuk pengiriman ekspor udara. Jurnal Manajemen Bisnis Transportasi dan Logistik (JMBTL) 5(3):339-352.

Niven PR. 2002. Balanced Scorecard: Step - By - Step Maximazing Performance and Maintaining Results. New York:John Wiley \& Sons, Inc.

Sapratama ER. 2016. Strategi Bbisnis untuk meningkatkan daya saing township Jakarta Garden City. Jurnal Bisnis dan Manajemen 52(11):254-269.

Suciyanti M, Haryadi H. 2018. Analisis SWOT Pengembangan ekonomi khusus industri Nikel di Provinsi Sulawesi Tenggara. Jurnal Teknologi Mineral dan Batubara 14(2): 159 - 177.

Sukanta, Sari D, Darajat A, 2018. Peningkatan pada analisis strategi pemasaran produk dies di PT KLM. Jurnal Riset Manajemen Sains Indonesia (JRMSI) 9(1): 79 - 87.

Suprapto, Lukman B, Kirbrandoko. 2017. Perencanaan strategik sbu mineral PT Sucofinfo (Persero). Jurnal Aplikasi Bisnis dan Manajemen 3(2):172194.

Sutrisno. 2017. ANALISIS STRATEGI PEMASARAN PT. RRG. Journal of Applied Business and Economics 4(2): 96-116.

Wheelen TL, David HJ. 2004. Strategic Management and Business Policy. New Jersey: Ninth Edition. Prentice Hall

Wijaya M.2017. Manajemen strategik dan budaya perusahaan: dampak serta implementasi. Media Informatika 16(2):195-207.

Winardi AM 2014. Strategi operasioal bisnis konsultan di Jakarta untuk meraih peluang yang lebih baik. . Jurnal MIX IV(2): 135 - 150.

Mackenzie W. 2018. Metals \& Mining Industry Analysis. Edinburg: Wodmac. 